DOI: 10.1515/arls-2017-0012

Research Article

\title{
Human Urine Alterations Caused by Apricot Seeds Consumption
}

\author{
Eva Tušimová ${ }^{1}$, Katarína Zbyňovská ${ }^{2}$, Anton Kováčik ${ }^{2}$, Katarína Michalcová ${ }^{2}$, Marek $^{2}$ \\ Halenár ${ }^{2}$, Anna Kolesárová ${ }^{3}$, Jana Kopčeková ${ }^{4}$, Jozef Valuch ${ }^{5}$, Adriana Kolesárová ${ }^{2}$ \\ ${ }^{1}$ Research Centre AgroBioTech, Slovak University of Agriculture, Tr. A. Hlinku 2, 94976 Nitra Slovakia \\ ${ }^{2}$ Department of Animal Physiology, Faculty of Biotechnology and Food Sciences, Slovak University of \\ Agriculture, Tr. A. Hlinku 2, 94976 Nitra Slovakia \\ ${ }^{3}$ Department of Plant Products Storage and Processing, Faculty of Biotechnology and Food Sciences, \\ Slovak University of Agriculture, Tr. A. Hlinku 2, 94976 Nitra Slovakia \\ ${ }^{4}$ Department of Human Nutrition, Faculty of Agrobiology and Food Resources, Slovak University of \\ Agriculture, Tr. A. Hlinku 2, 94976 Nitra Slovakia \\ ${ }^{5}$ Health Care Surveillance Authority, Žellova 2, 82924 Bratislava, Slovakia
}

\begin{abstract}
Amygdalin is a cyanogenic glucoside derived from various plants seeds. It is a natural product that owns antitumor activity, it has also been used for the treatment of asthma, bronchitis, emphysema, leprosy and diabetes and produces antitussive and antiasthmatic effects. The present in vivo study was designed to reveal whether amygdalin in apricot seeds has got an effect on human urine composition, $\mathrm{pH}$ value and urine associated health status after twelve weeks of oral administration. The study group finally consisted of 12 healthy adult volunteers. All participants consumed 60 $\mathrm{mg} / \mathrm{kg}$ of body weight of bitter apricot seeds daily (approximately $3.0 \mathrm{mg} / \mathrm{kg}$ of amygdalin) during 12 weeks. Two urine collections were carried out (at the beginning of the experiment and after 84 days). Quantification of urine calcium, magnesium, phosphorus, sodium, potassium, chlorides, urea and $\mathrm{pH}$ value after apricot seeds supplementation was performed. Paired t-test showed, that consumption of bitter apricot seeds during 84 days had a significant $(P<0.01)$ effect on amount of calcium excreted in urine, though this decrease shifted its level from elevated mean value in control collection into normal physiological range. No significant changes were observed in other parameters after apricot seed ingestion.
\end{abstract}

Key words: amygdalin, apricot seed, urine, minerals, urea.

\section{Introduction}

Plants contain a significant amount of biologically active substances able to lower a risk of civilization diseases [1, 2]. Glycosides and nitrilosides containing $\mathrm{CN}$ - (cyanide) exist in thousands of plants including strawberries, alfalfa sprouts, spinach, pecans, in particularly high concentration in apricot kernels and other seeds. These substances are responsible for their characteristically bitter taste. It should be noted

\section{* Corresponding author: Eva Tušimová, tusimova.eva@gmail.com}

(cc) BY-NC-ND $\odot 2017$ Eva Tušimová et al., published by De Gruyter Open This work was licensed under the Creative Commons Attribution-NonCommercialNoDerivs 3.0 License that bitterness could be important sensory indicator of potently anti-inflammatory, in excessive amounts also potentially poisonous compounds within a plant [3].

Amygdalin is a cyanogenic glucoside derived from seeds of rosaceous plants, for example seeds of bitter almonds (Prunus dulcis), or apricot, cherry, apple, peach, plum, etc. [4, 5, 6, 7]. Amygdalin $\mathrm{C}_{20} \mathrm{H}_{27} \mathrm{NO}_{11}$, is composed of one molecule of benzaldehyde, two molecules of glucose and one molecule of hydrocyanic acid [8].

It is a natural product that owns antitumor activity, less side effects and relatively low priced [9]. Besides the antitumor activity, amygdalin has also been used for the treatment of asthma, bronchitis, emphysema, leprosy and diabetes [10]. It is 
decomposed by the action of $\beta$-D-glucosidase to yield hydrocyanic acid which stimulates the respiratory centre reflexively and produces a kind of antitussive and antiasthmatic effects [11, 12].

It is not surprising, that use of amygdalin is recently increasingly advocated as an anticancer therapy [13]. It can be applied orally by apricot seed or tablet ingestion, or by intravenously [14]. Cyanide from amygdalin can be released by the action of beta-glucosidase or emulsin. Although these enzymes are not found in mammalian tissues, the human intestinal microflora appears to possess these or similar enzymes capable of effecting cyanide release resulting in human poisoning. For this reason, amygdalin may be as much as 40 times more toxic by the oral route as compared with intravenous injection [15]. It was reported, that after consumption of apricot seeds, cyanide can be produced in high enough level to cause a potential chronic toxicity problem [16]. In another study, Seghers et al. [17] stated that a daily intake of 70 apricot kernels during more than six weeks induces abnormal liver chemistry tests without other toxicity signs. However, in medicinal chemistry, there is a little distinction between a drug and poison, and the specific poisoning of cancer cells is also the basis of chemotherapy [3]. Urine may be a waste product, but it contains a great amount of information [18]. Urine is composed of $91-96 \%$ water [19], and the remainder can be characterized into inorganic salts, urea, organic compounds and organic ammonium salts [20]. Variation in its composition is caused by differences in physical exercise, environmental conditions, as well as water, salt and high protein intakes [21].

The present in vivo study was designed to reveal whether amygdalin in apricot seeds has got an effect on human urine composition, $\mathrm{pH}$ value and urine associated health status after twelve weeks of oral administration.

\section{Material and Methods \\ Chemicals}

Bitter apricot seeds were provided by Trasco (Žiar nad Hronom, Slovakia). Thin Layer Chromatography (TLC) was used for the analysis of amygdalin content in bitter apricot seeds used in our experiment. Grinded apricot seeds $(2 \mathrm{~g})$ were mixed with $10 \mathrm{ml}$ of methanol in a vial and put into ultrasonic bath for 30 minutes at $55^{\circ} \mathrm{C}$. After cooling, $10 \mu \mathrm{L}$ of solution was applied onto TLC plates Kieselgel UV 254 20×20 cm (Merck KGaA, Darmstadt, Germany). Mixture of $\mathrm{n}$ butanol, acetic acid and water (95:5:25) was used as a mobile phase. Separation took 5 hours at room temperature. After separation, amygdalin content was determined by UV densitometer CS -
9000 (Shimadzu, Japan) at wavelength $205 \mathrm{~nm}$. An external standard was used ( $1 \%$ amygdalin solution in methanol). Crude protein content was determined using Kjeldahl method [22], fat content was performed according to Soxhlet method for fat extraction [23] and crude fibre according to Henneberg-Stohmann method [24]. Amount of starch was measured via polarimetry and total sugars by Luff-Schoorl titration. Organic content in apricot seeds is shown in Table 1.

Table 1

Organic content in apricot seeds (\%).

(AMG = amygdalin)

\begin{tabular}{lc}
\hline Dry matter & 95.9 \\
\hline AMG & $\mathbf{5 . 8}$ \\
\hline Crude protein & 22.8 \\
\hline Fat & 39.7 \\
\hline Crude fibre & 28.5 \\
\hline Starch & 2.3 \\
\hline Total sugars & 6.3 \\
\hline
\end{tabular}

Amount of minerals in apricot seeds was determined using atomic absorption spectroscopy and is shown in Table 2.

Table 2

Dry matter (\%) and mineral content $(\mathrm{mg} / \mathrm{kg})$ in apricot seeds.

\begin{tabular}{lc}
\hline Dry matter & 95.9 \\
\hline $\mathrm{Ca}$ & 1774 \\
\hline $\mathrm{P}$ & 4700 \\
\hline $\mathrm{Mg}$ & 2050 \\
\hline $\mathrm{Na}$ & 642 \\
\hline $\mathrm{K}$ & 5925 \\
\hline
\end{tabular}

\section{Volunteers}

The study group finally consisted of 12 healthy adult volunteers - 5 females $(41.7 \%)$ and 7 $(58.3 \%)$ males. Volunteers were recruited from the general population of Slovakia (Nitra district). All subjects involved in the study were informed of all risks, discomforts and benefits and written informed consent to participate in the study was provided to them. The study was performed between September 2015 and January 2016. The trial was approved by the Ethic Committee at the Specialized Hospital St. Zoerardus Zobor, n. O., protocol number 030809/2015. All participants were asked to consume $60 \mathrm{mg} / \mathrm{kg}$ of body weight of bitter apricot seeds daily (approximately 3.0 $\mathrm{mg} / \mathrm{kg}$ of amygdalin) during 12 weeks. Volunteers were instructed as follows: not to change their 
usual diet and habits (physical exercise etc.), to consume approximately one seed each hour, to chew it as thoroughly as possible and to drink a lot of water after each consumption.

Urine sample collection

Two urine collections were carried out (first collection - at the beginning of the experiment used as a control; second collection - after 84 days). First morning sample of urine was collected from all volunteers into sterile tubes. Urine analysis was performed at the same day.

\section{Analysis}

Quantification of calcium (Ca), magnesium (Mg), phosphorus $(P)$ and urea after apricot seeds supplementation was performed through commercial sets DiaSys (Diagnostic Systems $\mathrm{GmbH}$, Germany) on device Rx Monza (Randox Laboratories Ltd., United Kingdom). Amount of sodium $(\mathrm{Na})$, potassium $(\mathrm{K})$ and chlorides $(\mathrm{Cl}-)$ was determined on device Easylyte Plus (Medica Corporation, United States). Urine $\mathrm{pH}$ values were measured by pH meter 3200P (Agilent Technologies, United States).

\section{Statistical analysis}

Parameters of human urine at the beginning of experiment and after 84 days of apricot seeds consumption were statistically evaluated and are given as means and SEM (standard error of the mean). All groups passed Shapiro-Wilk normality test and were compared by t-test using statistical software GraphPad Prism 5.0 (GraphPad Software Inc., San Diego, CA, USA). Differences were considered significant if the probability of error was $<5 \%$.

\section{Results and Discussions}

In past decades, amygdalin has been examined extensively. It has possible modulatory impact on cell viability [25] and the steroid production in porcine ovaries in vitro, as Halenár et al. [26, 27] reported in their study. Michalcová et al. [28] published, that natural substances present in apricot seeds may be involved in ovarian folliculogenesis mechanisms of rabbits through inhibition of FSH (follicle-stimulating hormone) levels. Amygdalin is also a potential antifibrotic agent that may have therapeutic potential for patients with fibrotic kidney disease [29]. Kovacova et al. [30] observed significantly lower values of primary osteons' vascular canals and secondary osteons in femoral bones of rabbits administered by amygdalin. Our previous in vivo study on rabbits showed no obvious effect of intramuscular administration of amygdalin (0.6 and $3.0 \mathrm{mg} / \mathrm{kg}$ ) on energy profile [31]. Similarly, Miller et al. [32] did not observe significant changes in blood chemistry of rats fed a diet containing $10 \%$ ground apricot seeds.

There are just a few studies of blood chemistry changes and even fewer studies of urine composition changes after amygdalin administration in vivo.

In our study, total of 12 adult volunteers were used in the final data analysis, of which $5(41.7 \%)$ were females and 7 (58.3\%) were males. Effect of 84 days of apricot seeds consumption on urine concentration of $\mathrm{Ca}, \mathrm{P}, \mathrm{Mg}, \mathrm{Na}, \mathrm{K}, \mathrm{Cl}$, urea and $\mathrm{pH}$ value was revealed by paired t-test $(\mathrm{P}<0.05$, $P<0.01, P<0.001$.).

Figure 1 shows the concentrations of the urine calcium. We found statistically significant decrease of $\mathrm{Ca}$ content after 84 days of apricot seeds consumption $(P<0.01)$. However, this decrease may be considered as a positive effect, since the reduction of excreted calcium shifted its level from elevated mean value in control collection (3.98 $\mathrm{mmol} / \mathrm{L})$ into normal physiological range $(1.2-3.7 \mathrm{mmol} / \mathrm{L})$ according to Vasudevan et al. [33].

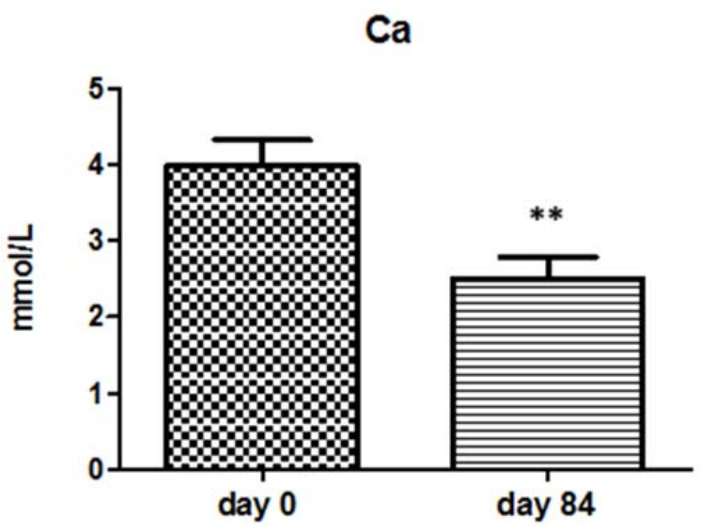

Fig. 1. Urine levels of calcium (mean \pm SEM). The level of significance was set at ${ }^{\star} P<0.05$, ${ }^{\star \star} P<0.01$, ${ }^{* * *} P<0.001$.

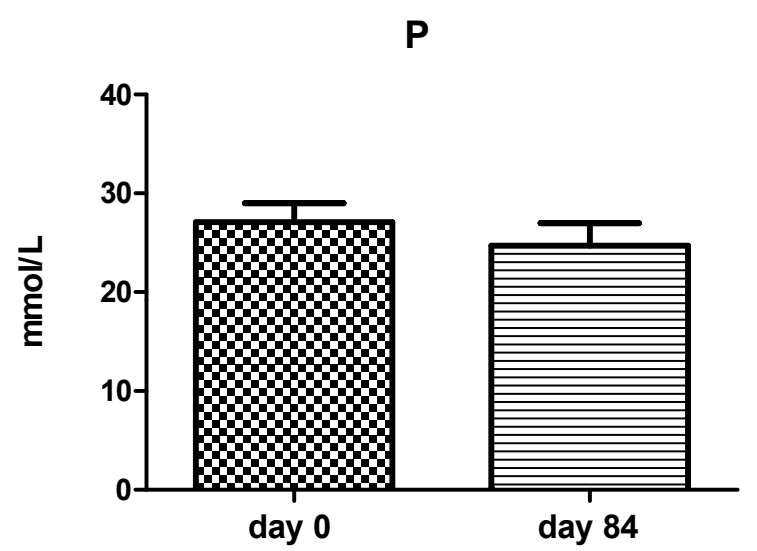

Fig. 2. Urine levels of phosphorus (mean \pm SEM). The level of significance was set at ${ }^{*} P<0.05$, ${ }^{* *} P<$ $0.01,{ }^{* * *} P<0.001$. 
The concentration of phosphorus in urine did not change significantly (Figure 2). Only a slight decrease of $\mathrm{P}$ content was observed, though all the values were in the reference range $(20-50$ $\mathrm{mmol} / \mathrm{L})$ [33].

Figure 3 describes how apricot seeds consumption influenced level of urine magnesium. We didn't found significant differences, however we found a moderate decrease of the observed parameter.

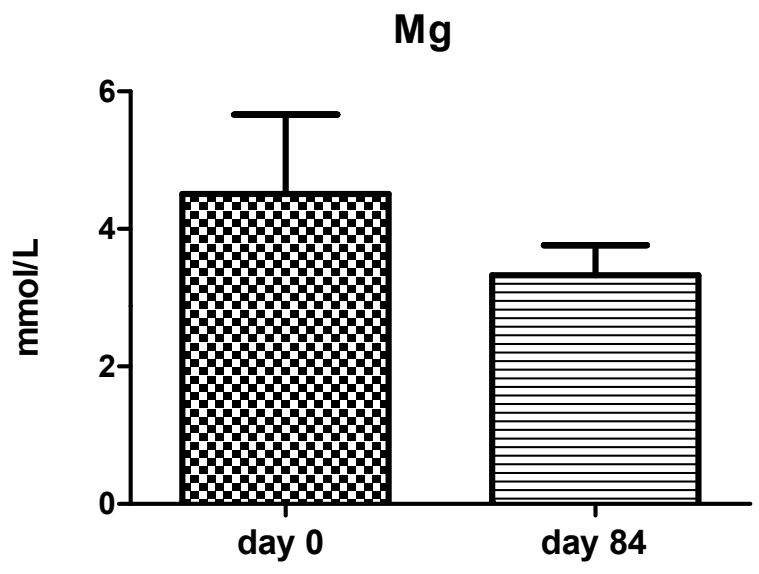

Fig. 3. Urine levels of magnesium (mean \pm SEM). The level of significance was set at ${ }^{\star} P<0.05$, ${ }^{*} P<$ $0.01,{ }^{* * *} P<0.001$.

Sodium and potassium are major solutes excreted in urine [21]. In very low protein diets, urine potassium level can be increased and magnesium concentration in urine is not affected [34]. Content of the urine sodium, potassium and chlorides showed only a slight increase after 84 days of consummation with non-significant differences (Figures 4, 5 and 6).

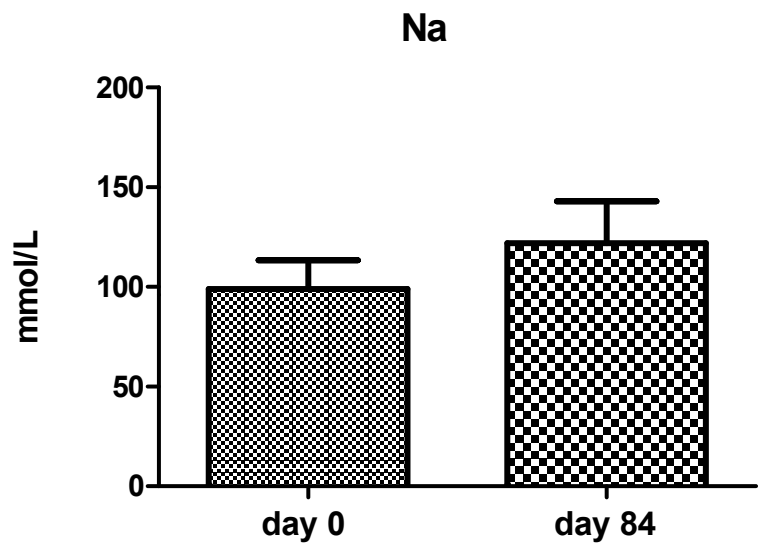

Fig. 4. Urine levels of sodium (mean \pm SEM). The level of significance was set at ${ }^{\star} P<0.05$, ${ }^{* \star} P<0.01$, ${ }^{* * *} P<0.001$.

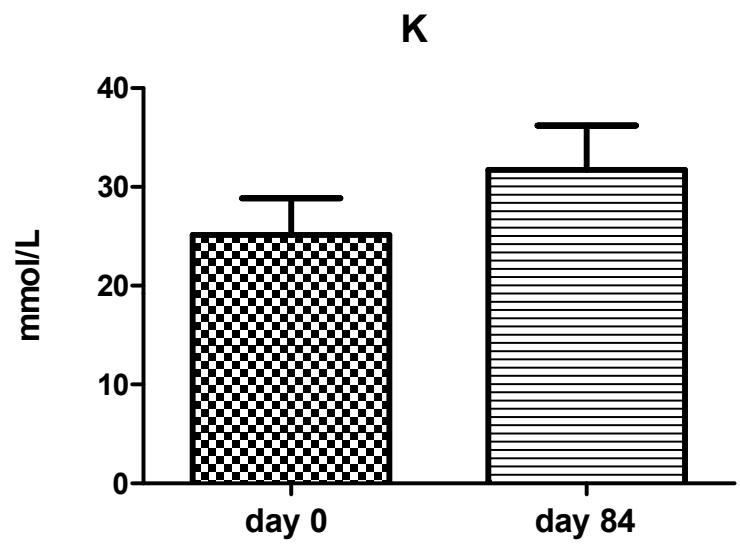

Fig. 5. Urine levels of potassium (mean \pm SEM). The level of significance was set at ${ }^{*} P<0.05$, ${ }^{\star *} P<0.01$, ${ }^{* * *} P<0.001$

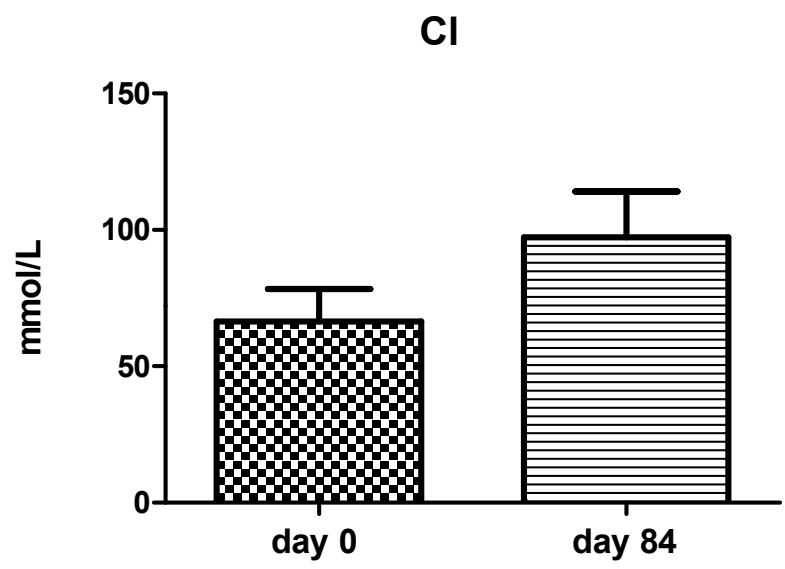

Fig. 6. Urine levels of chlorides (mean \pm SEM). The level of significance was set at ${ }^{*} P<0.05$, ${ }^{* *} P<0.01$, ${ }^{* * *} P<0.001$.

Content of urea showed a slight non-significant decrease after 12 weeks of apricot seeds consumption (Figure 7). Nitrogen in urine is predominantly in the form of organic nitrogen and mostly in the form of urea [35]. Urea is the most predominant constituent making up over one half of total organic solids, and it is produced through the metabolism of proteins [21]. Urinary nitrogenous components increase with levels of protein in the diet; a positive correlation between urinary nitrogen and protein intake was found to be 0.91 [36]. Normal urea concentration range from $167 \mathrm{mmol} / \mathrm{L}$ to $583 \mathrm{mmol} / \mathrm{L}$ [33]. Results of our study showed concentrations of urea within this range with non-significant decreasing tendency Vasudevan et al. [33] reported, that urea level decrease may be caused by low protein intake, prolonged fasting, but also by liver failure. However, our previous in vivo study on rabbits showed no obvious effect of amygdalin 
administration (0.6 and $3.0 \mathrm{mg} / \mathrm{kg}$ ) on hepatic profile after [37].

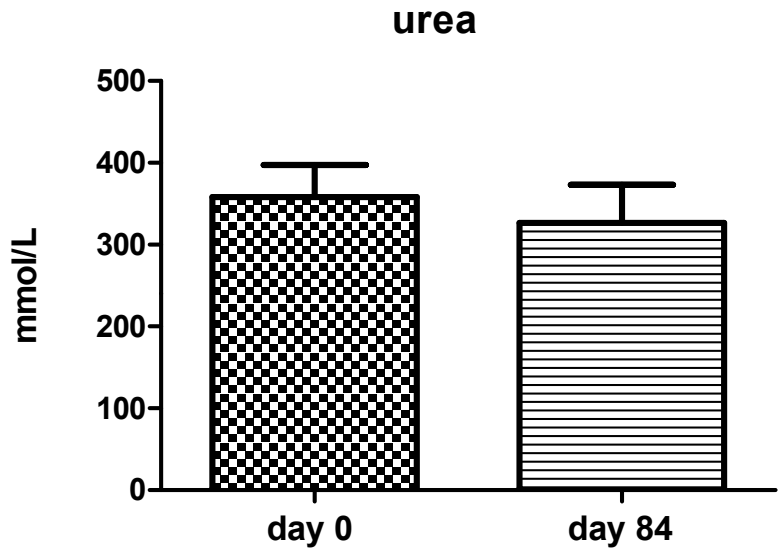

Fig. 7. Urine levels of urea (mean \pm SEM). The level of significance was set at ${ }^{*} P<0.05$, ${ }^{* *} P<0.01$, ${ }^{* * *} P$ $<0.001$.

The t-test of last studied parameter, $\mathrm{pH}$ value showed only negligible effect of apricot kernels consumption (Figure 8). Changes in urinary $\mathrm{pH}$ can be caused by numerous factors. It is reduced by high protein intake through meat and dairy products as well as through alcohol consumption [38] and increased by higher consumption of potassium and organic acids in vegetables and fruit [21].

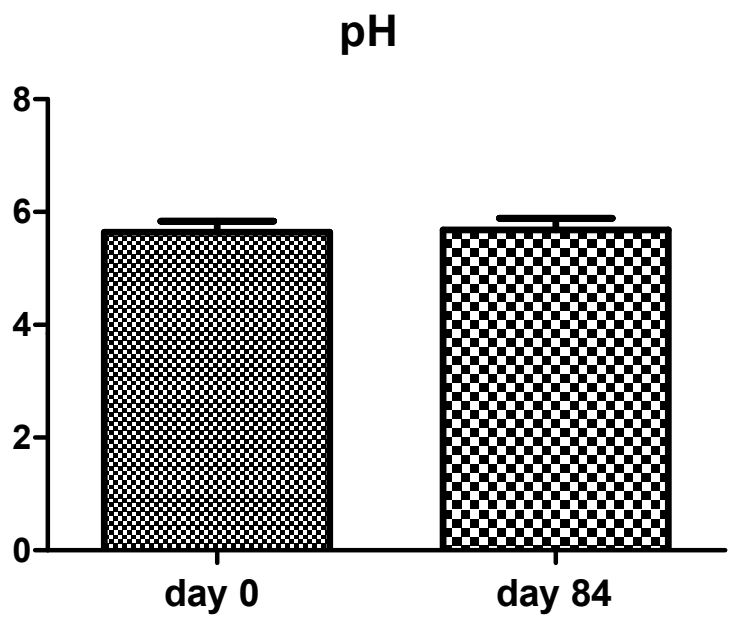

Fig. 8. Urine levels of $\mathrm{pH}$ (mean \pm SEM). The level of significance was set at ${ }^{*} P<0.05$, ${ }^{\star \star} P<0.01$, ${ }^{* *} P<$ 0.001 .

Value of $\mathrm{pH}$ in our study varied from 4.9 to 6.5 , which is similar to values that Rose et al. [21] observed. According to their results, the $\mathrm{pH}$ of fresh urine was largely neutral with a median of $\mathrm{pH} 6.2$ with a range of $\mathrm{pH}$ values of 5.5-7.0. Our results showed no significant differences in $\mathrm{pH}$ values between urine collection after 84 days in and control collection.

\section{Conclusions}

To protect human health, it is very important to study effect of natural substances and to know the right harmless dose. In our study, consumption of bitter apricot seeds (60 mg/kg of body weight) during 84 days had no significant effect on human urine composition, except on calcium level. Although the detailed mechanisms behind the action of amygdalin remain undefined, we hypothesize that this natural substance may moderately affect mineral and nitrogen management and possibly acid-base balance of the body. However, future studies are required to investigate the mechanisms by which amygdalin affects regulatory systems in human organism.

\section{Acknowledgements}

This work was financially supported by the Ministry of Education, Science, Research and Sport of the Slovak Republic projects no. 1/0039/16, 011SPU-4/2016 KEGA, APVV-030412, and European Community under project no. 26220220180: Building Research Centre „AgroBioTech".

\section{References}

1. Jakubcova, Z., Zeman, L., Mares, P., Mlcek, J., Jurikova T., Dostalova, L., Mrazkova, E., Mrkvicova, E., Balla, S., Sochor, J. (2014) Effect of chamomile supplements to feeding doses on antimicrobial parameters in poultry. Potravinarstvo Slovak Journal of Food Sciences, 8, 228-232. http://dx.doi.org/10.5219/383

2. Mendelová, A., Mendel, L., Czako, P., Mareček, J. (2016) Evaluation of carotenoids, polyphenols content and antioxidant aktivity in the sea buckthorn fruit juice. Potravinarstvo Slovak Journal of Food Sciences, 10, 59-64. http://dx.doi.org/10.5219/551

3. Sokolsky, M. L., Wargovich, M. J. (2012) Homeostatic Imbalance and Colon Cancer: The Dynamic Epigenetic Interplay of Inflammation. Environmental Toxins, and Chemopreventive Plant Compounds, Frontiers in oncology, 2(57), 1-21. http://dx.doi.org/10.3389/fonc.2012.00057

4. Holzbecher, M. D., Moss, M. A., Ellenberger, H. A. (1984) The cyanide content of laetrile preparations, apricot, peach and apple seeds. Journal of Toxicology, Clinical Toxicology, 22(4), 341-347.

5. Chwalek, M., Plé, K. (2004) Convenient syntheses of isomaltose derivatives from amygdalin. Tetrahedron Letters, 45, 4749-4753. http://dx.doi.org/10.1016/j.tetlet.2004.04.057

6. Santos Pimenta, L. P., Schilthuizen, M., Verpoorte, R., Choi, Y.H. (2013) Quantitative analysis of amygdalin and prunasin in Prunus serotina Ehrh. using (1) H-NMR spectroscopy. Phytochemical analysis PCA, 25(2), 122-126. http://dx.doi.org/10.1002/pca.2476. Epub 2013 Sep 23 
7. Lee, H. M., Moon, A. (2016) Amygdalin Regulates Apoptosis and Adhesion in Hs578T Triple-Negative Breast Cancer Cells. Biomolecules \& therapeutics, 24(1),

62-66. http://dx.doi.org/10.4062/biomolther.2015.172

8. Chang, H.K., Shin, M.S., Yang, H.Y., Lee, J.W., Kim, Y.S., Lee, M.H., Kim, J., Kim, K.H., Kim, C.J. (2006) Amygdalin Induces Apoptosis through Regulation of $\mathrm{Bax}$ and $\mathrm{Bcl}-2$ Expressions in Human DU145 and LNCaP Prostate Cancer Cells. Biological and Pharmaceutical Bulletin, 29, 1597-1602. http://dx.doi.org/10.1248/bpb.29.1597

9. Song, Z., Xu, X. (2014) Advanced research on antitumor effects of amygdalin. Journal of Cancer Resesarch \& Therapy, 1, 3-7. http://dx.doi.org/10.4103/0973-1482.139743

10. Zhou, C., Qian, L., Ma, H., Yu, X., Zhang, Y., Qu, W., Zhang, X., Xia, W. (2012) Enhancement of amygdalin activated with $\beta$-D-glucosidase on HepG2 cells proliferation and apoptosis. Carbohydrate Polymers, 90, 516-523. http://dx.doi.org/10.1016/j.carbpol.2012.05.073

11. Badr, J.M., Tawfik, M.K. (2010) Analytical and pharmacological investigation of amygdalin in Prunus armeniaca L. kernels. Journal of Current Pharmaceutical Research, 3, 2134-2137.

12. Lv, W.F., Ding, M. Y., Zheng, R. (2005) Isolation and quantitation of amygdalin in apricot kernel and Prunus Tomentosa Thunb. by HPLC with solid phase extraction. Journal of Chromatographic Science, 43, 383-387. http://dx.doi.org/10.1093/chromsci/43.7.383

13. Milazzo, S., Ernst, E., Lejeune, S., Boehm, K., Horneber, M. (2011) Laetrile treatment for cancer. The Cochrane Database of Systematic Reviews (CD005476).

http://dx.doi.org/10.1002/14651858.CD005476.pub3

14. Moertel, C. G., Fleming, T. R., Rubin, J., Kvols, L. K., Sarna, G., Koch, R., Currie, V. E., Young, C. W., Jones, S. E., Davignon, J. P. (1982) A clinical trial of amygdalin (Laetrile) in the treatment of human cancer. The New England Journal of Medicine, 306, 201-206.

http://dx.doi.org/10.1056/NEJM198201283060403

15. Casarett, L. J., Doull, J., Klaassen, C. D., Amdur, M. D. (1980) Casarett and Doull's Toxicology, 2nd ed. New York : Macmillan Publishing, 328 pp. ISBN 978-800023-304-04.

16. Seigler, D. S. (1975) Isolation and characterization of naturally occurring cyanogenic compounds. Phytochemistry, 14, 9-29. http://dx.doi.org/10.1016/0031-9422(75)85001-1

17. Seghers, L., Walenbergh-van Veen, M., Salome, J., Hamberg, P. (2013) Cyanide intoxication by apricot kernel ingestion as complimentary cancer therapy. The Netherlands Journal of Medicine, 71, 496-498.

18. Delanghe, J., Speeckaert, M. (2014) Preanalytical requirements of urinalysis. Biochemia Medica, 24(1), 89-104. http://dx.doi.org/10.11613/BM.2014.011

19. Heinonen-Tanski, H., Sjöblom, A., Fabritius, H., Karinen, P. (2007) Pure human urine is a good fertiliser for cucumbers. Bioresource Technology, 98(1), 214217. http://dx.doi.org/10.1016/j.biortech.2005.11.024 20. Putnam, D. F. (1971) Composition and concentrative properties of human urine (CR-1802) [online], Washington, DC: NASA. p. 38. [cit. 2017-0328] Available at: https://ntrs.nasa.gov/archive/nasa/casi.ntrs.nasa.gov/19 710023044.pdf

21. Rose, C., Parker, A., Jefferson, B., Cartmell, E. (2015) The characterization of feces and urine: a review of the literature to inform advanced treatment technology. Critical Reviews in Environmental Science and Technology, 45, 1827-1879. http://dx.doi.org/10.1080/10643389.2014.1000761

22. Kjeldahl, J. (1883) New method for the determination of nitrogen in organic substances. Zeitschrift für analytische Chemie, 22 (1), 366-383.

23. Soxhlet, F. (1879) Die gewichtsanalytische Bestimmung des Milchfettes. Dinglers Polytechnisches Journal, 232, 461-465.

24. Henneberg, W., Stohmann, F. (1860) Beitrage zur Begrundung einer rationeller Futterung der Weiderkauer. Schmetschke und Sohn, Braunschweig.

25. Halenár, M., Tušimová, E., Nynca, A., Sadowska, A., Ciereszko, R., Kolesárová, A. (2016) Stimulatory effect of amygdalin on the viability and steroid hormone secretion by porcine ovarian granulosa cells in vitro. Journal of Microbiology, Biotechnology and Food Sciences, $\quad 5 \quad$ (special1), 44-46. http://dx.doi.org/10.15414/jmbfs.2016.5.special1.44-46 26. Halenár, M., Medved'ová, M., Maruniaková, N., Kolesárová, A. (2015) Ovarian hormone production affected by amygdalin addition in vitro. Journal of Microbiology, Biotechnology and Food Sciences, 4, 1922. http://dx.doi.org/10.15414/jmbfs.2015.4.special2.1922

27. Halenár, M., Medved'ová, M., Maruniaková, N., Kolesárová, A. (2015) Assessment of a potential preventive ability of amygdalin in mycotoxin-induced ovarian toxicity. Journal of Environmental Science and Health $B, \quad 50(6), \quad 411-416$. http://dx.doi.org/10.1080/03601234.2015.1011956

28. Michalcová, K., Halenár, M., Tušimová, E., Kováčik, A., Chrastinová, L'., Ondruška, L'., Jurčík, R., Kolesárová, A. (2016) Blood plasma levels of anterior pituitary hormones of rabbits after apricot seed exposure in vivo. Journal of Central European Agriculture, 17(4), 1241-1252. http://dx.doi.org/10.5513/JCEA01/17.4.1838

29. Guo, J., Wu, W., Sheng, M., Yang, S., Tan, J. (2013) Amygdalin inhibits renal fibrosis in chronic kidney disease. Molecular Medicine Reports, 7, 14531457. http://dx.doi.org/10.3892/mmr.2013.1391

30. Kovacova, V., Omelka, R., Sarocka, A., Sranko, P., Adamkovicova, M., Toman, R., Halenar, M., Kolesarova, A., Martiniakova, M. (2016) Histological analysis of femoral bones in rabbits administered by amygdalin. Potravinarstvo, Slovak Journal of Food Sciences 10 (1), 393-399. http://dx.doi.org/10.5219/625 31. Tušimová, E., Kováčik, A., Halenár, M., Zbyňovská, K., Chrastinová, L', Ondruška, L'., Jurčík, R., Kolesár, E., Kolesárová, A. (2016) Energetic profile of rabbits after amygdalin administration. Journal of Microbiology, Biotechnology and Food Sciences, 5 (special 1), 50-52. http://dx.doi.org/10.15414/jmbfs.2016.5.special1.50-52 32. Miller, K. W., Anderson, J. L., Stoewsand, G. S. (1981) Amygdalin metabolism and effect on 
reproduction of rats fed apricot kernels. Journal of Toxicology and Environmental Health, 7, 457-467. http://dx.doi.org/10.1080/15287398109529994

33. Vasudevan, D. M., Sreekumari, S., Vaidyanathan, K. (2011) Textbook of Biochemistry for Medical Students, 6th edition. New Delhi : Jaypee Brothers Medical Publishers, pp. 332-339.

34. Calloway, D. H., Margen, S. (1971) Variation in endogenous nitrogen excretion and dietary nitrogen utilization as determinants of human protein requirement. The Journal of Nutrition, 101(2), 205-216.

35. Beler-Baykal, B., Allar, A., and Bayram, S. (2011) Nitrogen recovery from source-separated human urine using clinoptilolite and preliminary results of its use as fertilizer. Water Science and Technology, 63(4), 811817. http://dx.doi.org/10.2166/wst.2011.324.

36. Magee, E. A., Curno, R., Edmond, L. M., and Cummings, J. H. (2004) Contribution of dietary protein and inorganic sulfur to urinary sulfate: Toward a biomarker of inorganic sulfur intake. The American Journal of Clinical Nutrition, 80(1), 137-142.

37. Tušimová, E., Kováčik, A., Halenár, M., Zbyňovská, K., Tomková, M., Tirpák, F., Chrastinová, L'., Ondruška, L'., Jurčík, R., Kolesár, E., Kolesárová, A. (2016) Hepatic profile of female rabbits after amygdalin administration, 12th International Scientific Conference Animal Physiology 2016 : proceedings. Bořetice : Mendel University in Brno, pp. 253-259. ISBN 978-80-7509-416-2.

38. Kanbara, A., Miura, Y., Hyogo, H., Chayama, K., and Seyama, I. (2012) Effect of urine pH changed by dietary intervention on uric acid clearance mechanism of $\mathrm{pH}$-dependent excretion of urinary uric acid. Nutrition Journal, 11(1), p. 39. http://dx.doi.org/10.1186/14752891-11-39 